\title{
Siphonal tube structure of the Late Devonian orthocerid Dolorthoceras from the Polar Urals (NW Russia) preserving nacre and organic fibres as well as its persistence in cephalopod evolution
}

\author{
Larisa A. Doguzhaeva'
}

Received: 3 September 2018 / Accepted: 16 February 2019/Published online: 15 March 2019

(c) The Author(s) 2019

\begin{abstract}
A juvenile orthocerid Dolorthoceras sp. from the Frasnian (Late Devonian) of the Polar Urals in NW Russia is the first recorded ectocochleate cephalopod showing fibrous structures and the first Devonian cephalopod preserving nacreous structures within its conch. Like Nautilus, Dolorthoceras sp. has columnar nacre in its shell wall and septa, which are composed of differentiated nacreous tablets that are c. $3 \mu \mathrm{m}$ and $10 \mu \mathrm{m}$ in diameter. The central, small, cylindrical, hollow siphonal tube-studied in median section using scanning electron microscope-comprises short columnar-nacreous suborthochoanitic septal necks and thin, apparently primarily chitinous, connecting rings; swollen, lens-shaped in median section, two-part fibrous non-biomineralized structures-here named clutches-envelope the posterior parts of the septal necks. Together with the adjacent connecting ring, the outer part of the clutch may extend onto adapical septal surfaces; their inner part and adjoining from inside next connecting ring line the septal neck. The clutches are comparable, to some degree, to the auxiliary deposits and cuffs of the siphonal tubes found in ammonoids; these are interpreted as being protective structures of the conjunctions between the connecting rings and septal necks reinforcing it against hydrostatic pressure, which was probably also the case in Dolorthoceras. Tracing the Silurian to Cretaceous longiconic cephalopods with narrow, central to eccentric, hollow siphonal tubes and swollen posterior portions of the septal necks shows that the Dolorthoceras-type siphonal tube may represent a conch structure that persisted throughout about 370 million-year-long evolutionary history of orthocerid cephalopods.
\end{abstract}

Keywords Cephalopoda - Orthocerida - Late Devonian · Columnar-nacreous and fibrous conch structures . Dolorthoceras-type siphonal tube $\cdot$ Polar Urals

\section{Introduction}

Longiconic cephalopods of the order Orthocerida with small central or eccentric siphuncles are known to range from the Early Ordovician at least until the end of the Triassic (Teichert and Glenister 1954; Balashov 1957; Balashov and Zhuravleva 1962; Sweet 1964; Teichert 1988; Webby et al. 2004; Evans 2005; Kröger 2008, 2013; Kröger and Landing 2008) and according to Doguzhaeva (1994) until the Early Cretaceous. Consequently, together

Editorial Handling: C. Klug.

Larisa A. Doguzhaeva

larisa.doguzhaeva@gmail.com; larisa.doguzhaeva@nrm.se

1 Department of Palaeobiology, Swedish Museum of Natural History, PO Box 50007, 10405 Stockholm, Sweden with Nautiloidea and Ammonoidea, they survived the Late Devonian, Late Permian and Late Triassic mass extinction events. The terminal post-Triassic evolutionary history of orthoconic cephalopods represents " .... a prolonged interval during which the group... became so restricted in taxonomic scope and in habitat that fossil representatives are great rarities or have not yet been identified at all" (Teichert 1988: p. 70). Apart from the Eocene-aged orthoconic paracoleoid Antarcticeras (Doguzhaeva et al. 2017; Doguzhaeva 2018a, b, c; for a different opinion see Fuchs et al. 2018), post-Triassic phragmocone-bearing orthoconic cephalopods are so far known only from a single specimen of the Aptian (Early Cretaceous) orthocerid Zhuravlevia insperata from the northwestern Caucasus, Adygeya Republic, SW Russia (Doguzhaeva 1994).

Recent research of the siphonal tube structures of diverse extinct cephalopods required to better understand 
their palaeobiology and phylogeny is hampered by the widespread diagenetic destruction of the primary nacreous, organic-rich and non-biomineralized conch structures (see Gnoli 1982; Zhuravleva and Doguzhaeva 1999, 2004; Evans 2005; Niko et al. 2007; Kröger 2008; Niko and Sone 2015; Mutvei 2015, 2016, 2017; Mutvei and Mapes 2018). The Palaeozoic orthoconic cephalopods showing nacre preservation have been hitherto restricted to several genera of Early Carboniferous to early Permian age (see Erben et al. 1969; Ristedt 1971; Mutvei 1972, 2017; Hewitt 1982; Blind 1988; Doguzhaeva and Shkolin 1999; Doguzhaeva 2002a; Kröger and Mapes 2005; Seuß et al. 2012a, b; Niko et al. 2018; De Baets and Munnecke 2018). The fibrous conch ultrastructures were so far reported in Jurassic gladii of 'fossil squids' (Doguzhaeva and Mutvei 2003).

The present paper describes a juvenile orthocerid Dolorthoceras sp., which represents the first time that preserving nacreous structures are recorded from a Devonian cephalopod and fibrous structures within its conch are documented from an ectocochleate cephalopod. This exceptionally well-preserved minute specimen comes from the Domanic Formation (Frasnian, Upper Devonian) from the River Malaya Usa Basin on the west slope of the Polar Urals (Komi Republic, NW Russia). It was collected in the 50 s by G. A. Chernov who carried out a valuable study on biostratigraphy of Devonian strata in this Region (Chernov 1961, 1962, 1972). Along with the larger sized orthocones collected from the Domanic Formation in River Malaya Usa Basin, Chernov transferred this tiny specimen of Dolorthoceras in the 60s to F. A. Zhuravleva of the Paleontological Institute, Moscow (Zhuravleva 1978: pp. 29, 35, 37; pl. 2, fig. 7 ; pl. 12, fig. 5; pl. 17, fig. 3; pl. 18, fig. 3). Later, this yet unpublished specimen was selected for the project "The shell ultrastructure in some extinct groups of cephalopods and its bearing for phylogeny" (funded by Grants 5MG 000 and 5MG 300 from the International Scientific Foundation in collaboration with G. Soros and the Moscow Government; 1994-1996: see Doguzhaeva et al. 1996; Doguzhaeva and Shkolin 1999; Doguzhaeva 1996a, b, 2002a; Zhuravleva and Doguzhaeva 1999, 2004). The siphonal tube structures and ultrastructures of this Dolorthoceras sp. are the main focuses of this paper.

\section{Material, study method and terminology}

One-minute specimen of Dolorthoceras sp. (no. PIN-1894/ 100, Paleontological Institute of the Russian Academy of Sciences, Moscow) from the Domanic Formation (Frasnian, Late Devonian) of the River Malaya Usa Basin in the Polar Urals (Komi Republic, NW Russia) is the main specimen examined in this study. The exact locality where the specimen was found is unknown.

The conch has been sectioned longitudinally through the plane of the siphonal tube. It was then polished, etched with a $2 \%$ solution of acetic acid and examined using a scanning electron microscope.

A new term 'clutch' is here applied to the swollen, lens shaped in median section, non-biomineralized fibrous structures of the siphonal tube that envelopes the posterior parts of septal necks and are placed between the short columnar-nacreous septal necks and thin non-biomineralized connecting rings.

\section{Description}

Phragmocone form The specimen is a 20-mm-long fragment of a smooth, longiconic phragmocone with a minimum diameter of $2 \mathrm{~mm}$ and a maximum diameter of $5 \mathrm{~mm}$. The phragmocone comprises ten moderately long chambers and exhibits a small central siphuncle, short suborthochoanitic septal necks and thin connecting rings (Figs. 1, 2).

Remarks The internal phragmocone structure resembles that of another (medium-sized) specimen of Dolorthoceras sp. from the same area (Zhuravleva 1978: pl. 12, fig. 5). Judging from the small conch diameter and distribution of mural and episeptal cameral deposits, which are present in the apical six chambers and absent from the adoral four chambers (Fig. 1), the studied specimen represents a partially preserved phragmocone of a juvenile conch.

Shell wall The bulk of the shell wall thickness is formed by a nacreous layer that is coated by thin outer and inner prismatic layers; the latter is particularly indistinct (barely visible) and weakly developed at this ontogenetic stage (Fig. 3). The nacreous layer shows a columnar arrangement of nacreous tablets; narrow hollow interspaces between the columns may have been originally filled with organic material, which is not preserved. On the external conch surface, the outer prismatic layer forms tiny transverse ridges, which result from the regularly arranged weak undulations and thickenings of this layer (Fig. 3); there are three to five ridges per chamber length. The inner surface of this prismatic layer is smooth.

Remarks With respect to shell wall ultrastructure, the juvenile Early Permian bactritids Chuvashovia and Hemibactrites from the southern Urals resemble the juvenile Dolorthoceras sp. described here. Their shell walls consist of outer prismatic and nacreous layers; the former is initially thicker than the latter; however, the nacreous layer rapidly becomes thicker than the outer prismatic layer 


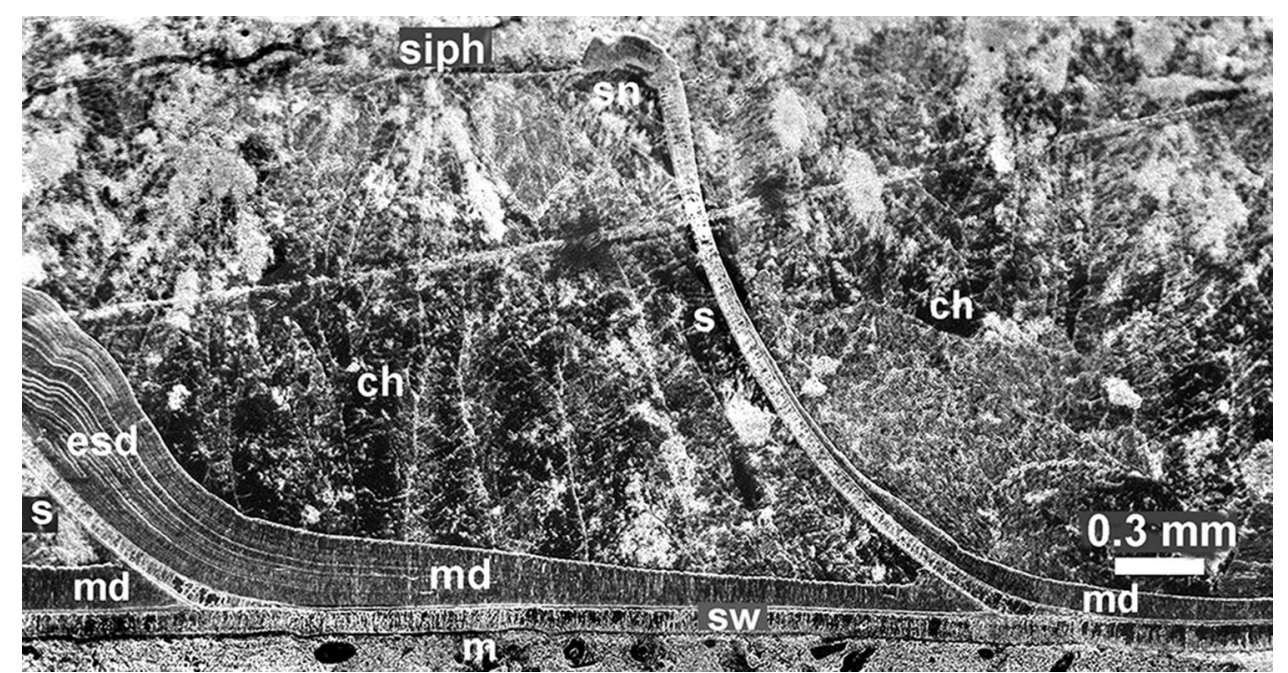

Fig. 1 Dolorthoceras sp. (PIN-1894/100); River Malaya Usa, Polar Urals, NW Russia; Frasnian, Late Devonian. Median conch section. The two last chambers containing cameral deposits, which are missing from the next chambers of the phragmocone. Note that in the right chamber, thin episeptal cameral deposits coat about half of the septal length but the mural deposits are about as thick as the shell wall; in the preceding chamber, the episeptal and mural deposits are thick, whereas the hyposeptal deposits are missing. Scale bar is $0.3 \mu \mathrm{m}$. ch chamber, esd episeptal cameral deposits, $m$ matrix, mural cameral deposits, $s$ septum, $s n$ septal neck, $s w$ shell wall

Fig. 2 Dolorthoceras sp. (PIN1894/100); River Malaya Usa, Polar Urals, NW Russia; Frasnian, Late Devonian. Median conch section. A detail of the siphonal tube to show thin, supposedly chitinous, connecting rings, short columnar-nacreous septal necks, and non-biomineralized fibrous lens shaped structures (sectioned clutch). Scale bar is $0.1 \mathrm{~mm}$. ch chamber, $\mathrm{cr}$ connecting ring, $l s$ lens-shaped structure, $s$ septum, siph siphuncle, sn septal neck

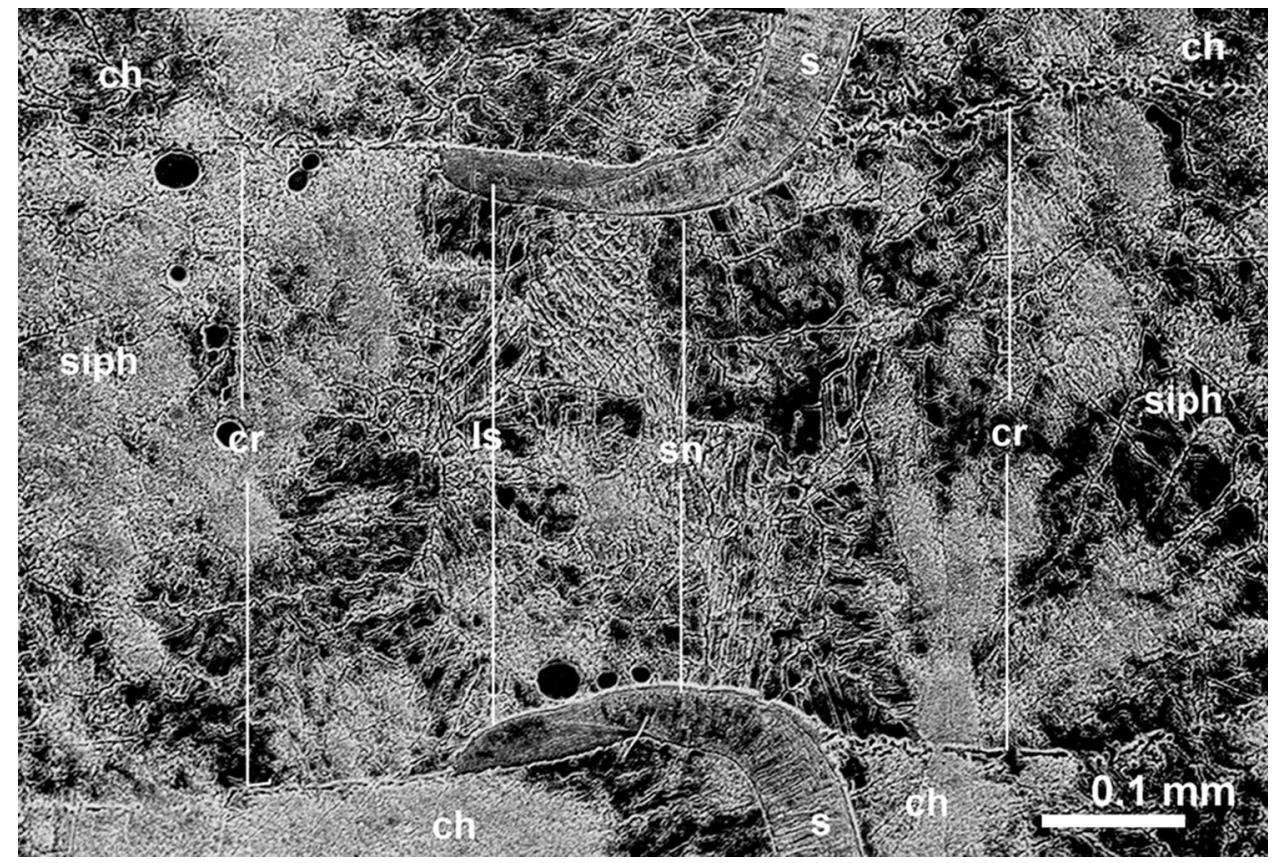

(Doguzhaeva 2002a: pl. 1, figs. 6, 7; pl. 3, figs. 1, 4, 5). Also, in the hatchlings of the Early Permian ammonoid Agathiceras from the Southern Urals, the shell wall consists of outer prismatic and nacreous layers; the inner prismatic layer is added at the third whorl (Doguzhaeva 2002a: pl. 10, figs. 7, 8). A three-layered shell wall ultrastructure, with the middle layer being composed of columnar nacre, is a trait of fully-grown conchs of ectocochleate cephalopods. It is illustrated, for example, in the Early Triassic orthocerid Trematoceras (Zakharov 1996: pl.
1, fig. 1). Also, in the Late Carboniferous orthocones with small central or eccentric siphuncles from the Buckhorn asphalt in the USA, the shell wall is composed of the outer prismatic, nacreous and inner prismatic layers (Erben et al. 1969; Ristedt 1971; Mutvei 1972; Blind 1988; Seuß et al. 2012a, b). In contrast, the extinct endocochleate cephalopods, except some belemnoids (Doguzhaeva et al. 2002, 2003, 2006) have, like Sepia and Spirula, an organic rich shell wall lacking a nacreous layer (more details are provided in Doguzhaeva 1994, 1996a, b, c, 2000, 
Fig. 3 Dolorthoceras sp. (PIN1894/100); River Malaya Usa, Polar Urals, NW Russia; Frasnian, Late Devonian. Median conch section. Columnar nacre in the septum and the shell wall indicates the exceptional preservation of this orthocone. Note that the tablets of nacre are, as in present day Nautilus, larger in the septa than in the shell wall. Scale bar is $30 \mu \mathrm{m}$. ch chamber, hsd hyposeptal cameral deposits, ipl inner prismatic layer, $m$ matrix, $m d$ mural cameral deposits, $n l$ nacreous layer, $o p l$ outer prismatic layer, $s$ septum, $s w$ shell wall

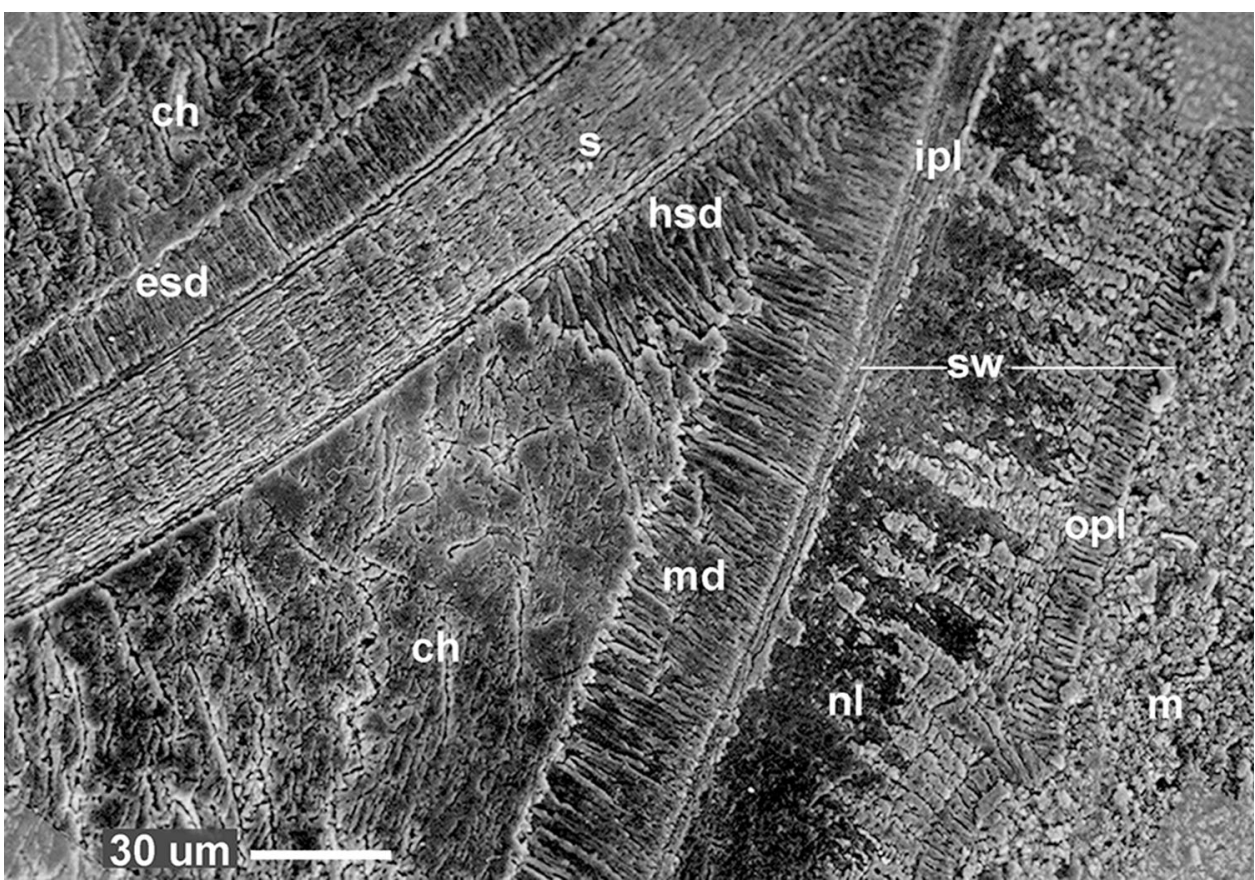

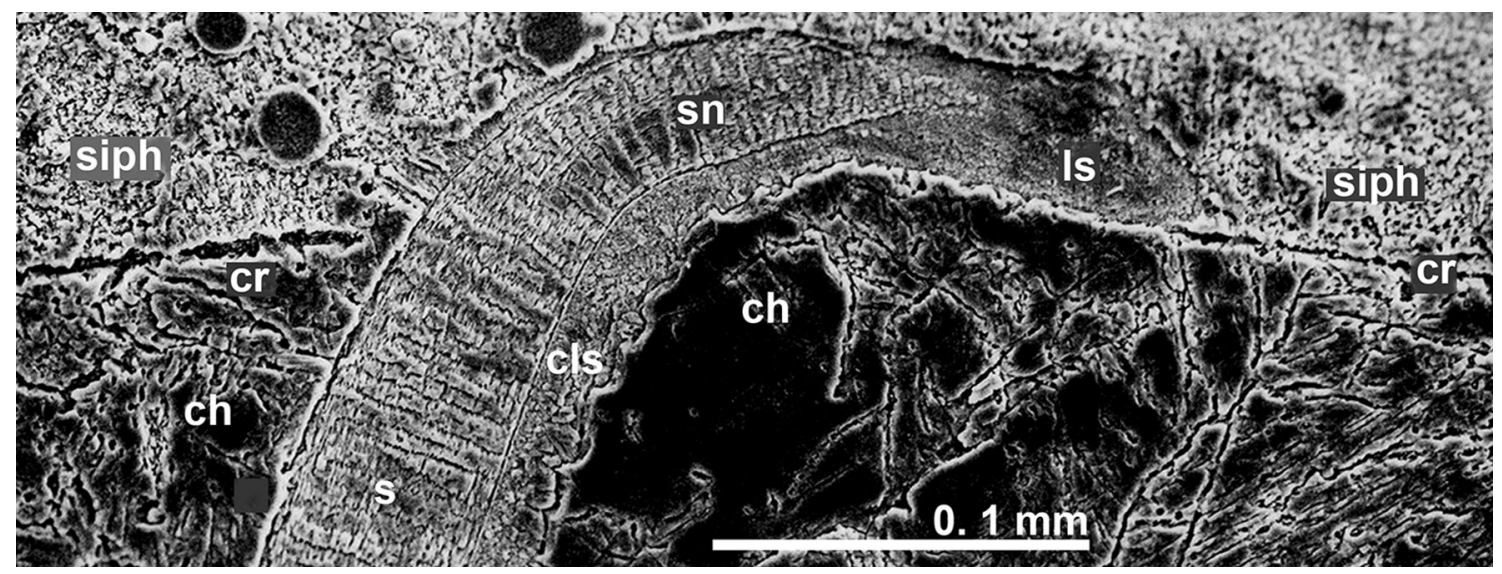

Fig. 4 Dolorthoceras sp. (PIN-1894/100); River Malaya Usa, Polar Urals, NW Russia; Frasnian, Late Devonian. Median conch section. The clutch along with thin connecting ring continues on the adapical septal surface. Note the ultrastructural difference between the regular mineralization of the septum and septal neck, on the one hand, and on the other

2002a, b, 2018a, b, c; Doguzhaeva et al. 1996, 1999, 2002b, 2003, 2017; Doguzhaeva and Mapes 2017). The assignment of the orthoconic cephalopods with different shell wall structures (ectocochleate or endocochleate types, see above) to the same order within the Nautiloidea (Mutvei 2017) is here considered to be misleading.

Septa The septa are columnar-nacreous and, like the shell wall, composed of tablets of nacre arranged in columns (Figs. 2, 3). The columns (and, hence, the nacreous tablets) are approximately three times larger within the septa than in the shell wall. The diameter of these columns is c. $10 \mu \mathrm{m}$ hand, the irregular mineralization of the clutch continutaion along septum indicative the post-mortem diagenetic fossilization of the primarily organic matter. Scale bar is $0.1 \mathrm{~mm}$. ch chamber, $c r$ connecting ring, $c l s$ clutch continuation along septum, $s$ septum, $l s$ lensshaped structure (sectioned clutch), siph siphuncle, sn septal neck

in the septa and c. $3 \mu \mathrm{m}$ in the shell wall. Narrow hollow interspaces between the columns were likely originally filled with organic material, which is not preserved. Septal surfaces are coated with thin non-biomineralized layers that are preserved where they are overlain by episeptal deposits or, on the adapical surface, by the elongation of the clutch (Figs. 4, 5).

Remarks The columnar-nacreous structure of septa (e.g., in Nautilus) is a trait of ectocochleate cephalopods while the lamellar-fibrillar nacreous structure of septa (e.g., in Sepia and Spirula) is a feature of endocochleate cephalopods 
Fig. 5 Dolorthoceras sp. (PIN1894/100); River Malaya Usa, Polar Urals, NW Russia; Frasnian, Late Devonian. Median conch section. Enlargement of Fig. 4, to show the prismatic ultrastructure of the episeptal cameral deposits, columnarnacreous ultrastructure of the septum and the irregular mineralization of the continuation of the clutch on the adapical septal surface. Note that both surfaces of the septum show thin whitish unstructured layers that may have been chitinous syn vivo. Scale bar is $10 \mu \mathrm{m}$. ch chamber, $c l$ clutch, $m$ matrix, $s$ septum, siph siphuncle

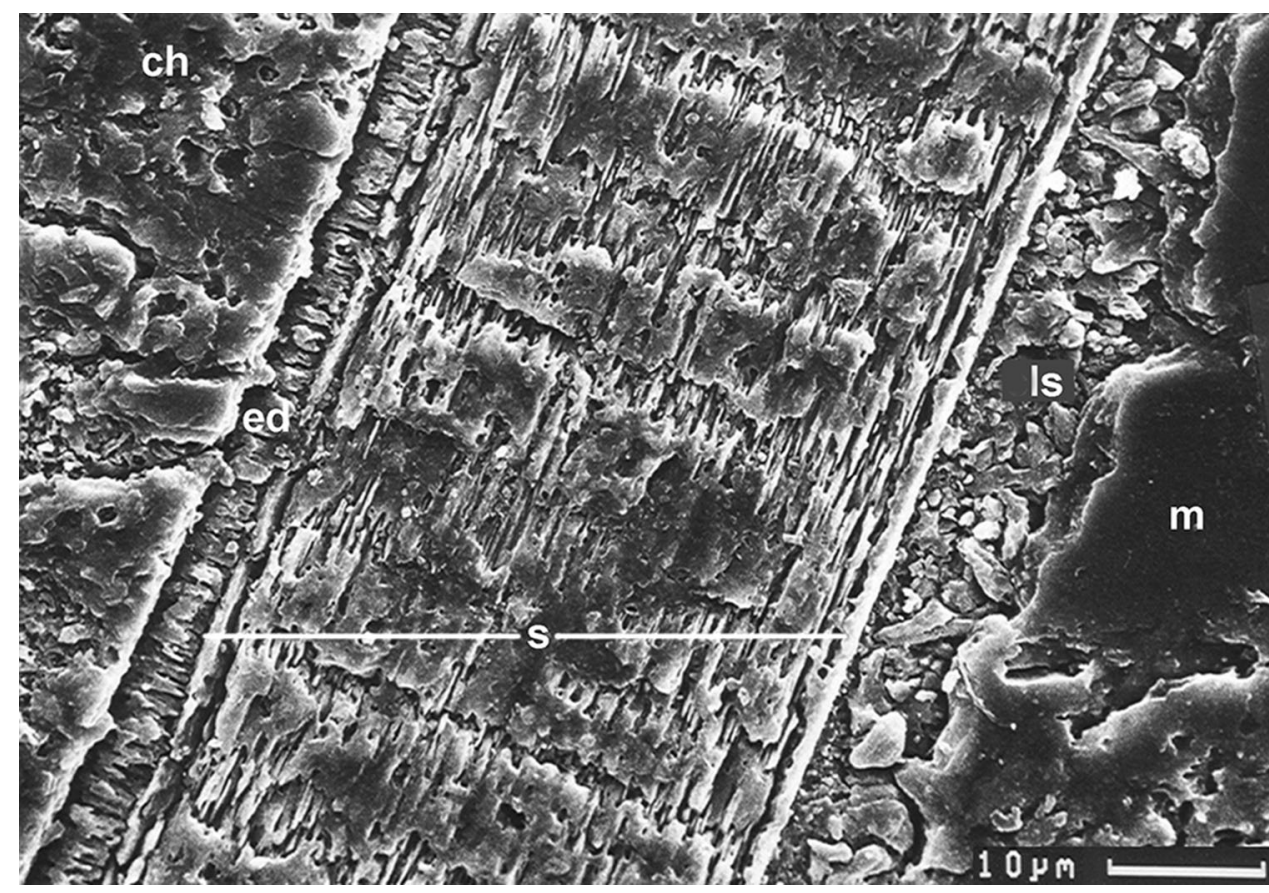

(further details in Doguzhaeva 1994, 1996c, 2002b, 2018a, b, c; Doguzhaeva and Dunca 2015; Doguzhaeva et al. 2014a, 2017). The phenomenon that nacreous tablets are larger in septa and smaller in the shell wall is also recorded in present day Nautilus (Mutvei 1972; Mutvei and Dunca 2010).

Siphonal tube: septal necks The septal necks are short suborthochoanitic (Figs. 1, 2, 4). As these are a continuation of septa, they are made solely, like septa, of columnar nacre (Figs. 2, 4, 6, 8). Their posterior parts are surrounded by the pronounced clutches, which are approximately as long as the corresponding septal neck (see below and Figs. 2, 4, 8, 9, 10a, b).

Siphonal tube: clutches These structures are non-biomineralized organic and consist of the fibrous inner and outer parts that show an ultrastructural pattern formed by the adaperturally converging organic fibres of the two parts (Figs. 2, 4, 6, 7, 8, 9, 10). The outer part of the clutch and the thin, non-biomineralized connecting ring adjacent from the outside, may continue on the adapical septal surface (Figs. 4, 5, 6, 9); the inner part, along with the connecting ring belonging to the next adjacent chamber, lines the septal neck (Figs. 2, 4, 6a, b, 9). In this manner, the clutches are situated within the connecting rings (Figs. 2, 4, 9, $10 \mathrm{a}, \mathrm{b})$. The elongation of the clutches on the adapical septal surface consists of irregularly shaped non-oriented particles (Figs. 4, 5). It differs from the prismatic cameral deposits or nacreous septa and apparently represents postmortem mineralised purely organic or organic-rich conch structure.
Remarks The clutches (= 'swollen posterior parts of septal necks') were described in the Early Cretaceous orthocerid Zhuravlevia (Doguzhaeva 1994). Because of the less wellpreserved shell material, they do not reveal a fibrous ultrastructure as seen in Dolorthoceras (Fig. 10a-d). Nevertheless, they also do not show a regular ultrastructure (Doguzhaeva 1994) and might have been originally organic as well. The Olenekian (Early Triassic) orthocerid Trematoceras reveals the thickened organic layers coating the posterior parts of the septal necks (Zakharov 1996: fig. 1; pl. 2, figs. 3, 4) that are similar to the clutches observed in Dolorthoceras and Zhuravlevia. Also, in the Late Carboniferous orthocones with small central or eccentric siphuncles from the Buckhorn asphalt, the 'swollen posterior parts of the septal necks' may indicate the presence of the clutches. Mutvei (1972) suggested that the conchiolin membranes of the septal necks continue to their swollen posterior structurally modified parts where the nacreous lamellae are substituted by prismatic ones. The converging fibres and bipartite structure of the clutches in Dolorthoceras sp. contradict this assumption. Blind (1988) described the spherulitic ultrastructure of the "swollen posterior parts of the septal necks' and assumed that they were, after secretion of the connecting ring, the attachment places of the epithelium of the siphuncle. In the light of new data on the fibrous ultrastructure of the clutches in the Devonian Dolorthoceras, it is highly probable that the mineralisation of the swollen structures coating the posterior parts of the septal necks in the orthoconic cephalopods is diagenetic. 
Fig. 6 Dolorthoceras sp. (PIN1894/100); River Malaya Usa, Polar Urals, NW Russia;

Frasnian, Late Devonian. Median conch section. a The ultrastructural difference between the columnar-nacreous septal neck and the fibrous lensshaped structure (sectioned clutch) coating the posterior part of the septal neck. Note that the thin connecting ring is adjacent to the outer surface of the clutch. Scale bar is $0.1 \mathrm{~mm}$. b Enlarged detail of A to show the fibrous ultrastructure of the lens-like structure (sectioned clutch). Scale bar is $30 \mu \mathrm{m}$. ch chamber, $c r$ connecting ring, $l s$ lens-shaped structure, $s$ septum, siph siphuncle, sn septal neck

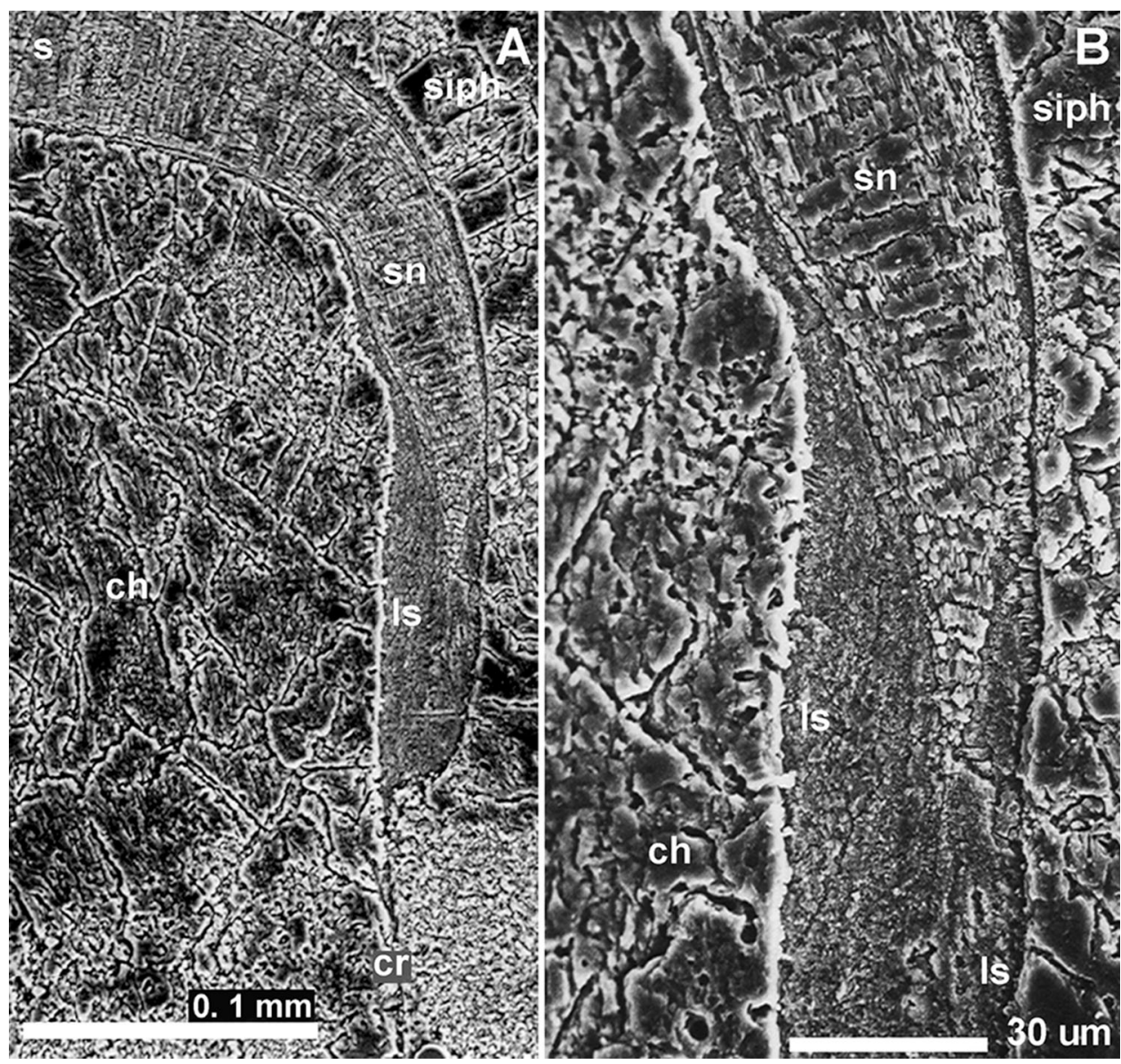

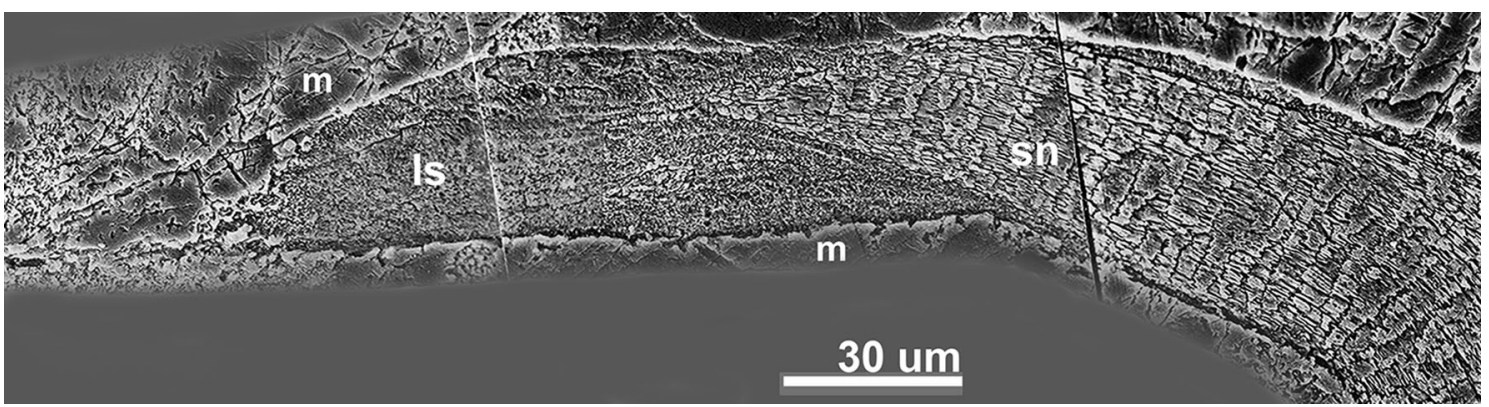

Fig. 7 Dolorthoceras sp. (PIN-1894/100); River Malaya Usa, Polar Urals, NW Russia; Frasnian, Late Devonian. Median conch section. The different fossilization of the biomineralized columnar-

Siphonal tube: connecting rings The connecting rings are thin, appear dark in the light microscope, homogenous, probably non-biomineralized, and were apparently originally chitinous (Figs. 1, 2, 4, 6). In each chamber, the anterior end of the connecting ring is adjacent to the outer part of the fibrous clutch and they continue together on the adapical septal surface (Figs. 2, 6, 10a, b). The posterior end of the connecting ring is adjacent to the inner part of the clutch at the preceding (adapical) septal neck (Fig. 6a, b). nacreous septal neck (to the right) and the primarily organic fibrous lens shaped structure (sectioned clutch) coating its posterior part. Scale bar is $30 \mu \mathrm{m}$. $l s$ lens shaped structure, $m$ matrix, $s n$ septal neck

Remarks Like in Dolorthoceras, thin, non-biomineralized connecting rings are preserved in the Early Cretaceous orthocerids Zhuravlevia (Doguzhaeva 1994: text-fig. 4A, B; pl. 2, fig. 4) and the Early Triassic orthocerid Trematoceras (Zakharov 1996). In these genera, the adoral ends of the connecting rings are also adjacent to the external part of the clutches rather than being directly attached to the septal necks (compare Figs. 2, 9, 10 here and pl. 2, fig. 4 in Doguzhaeva 1994). This may suggest that non-biomineralized connecting rings were a prerequisite of the 


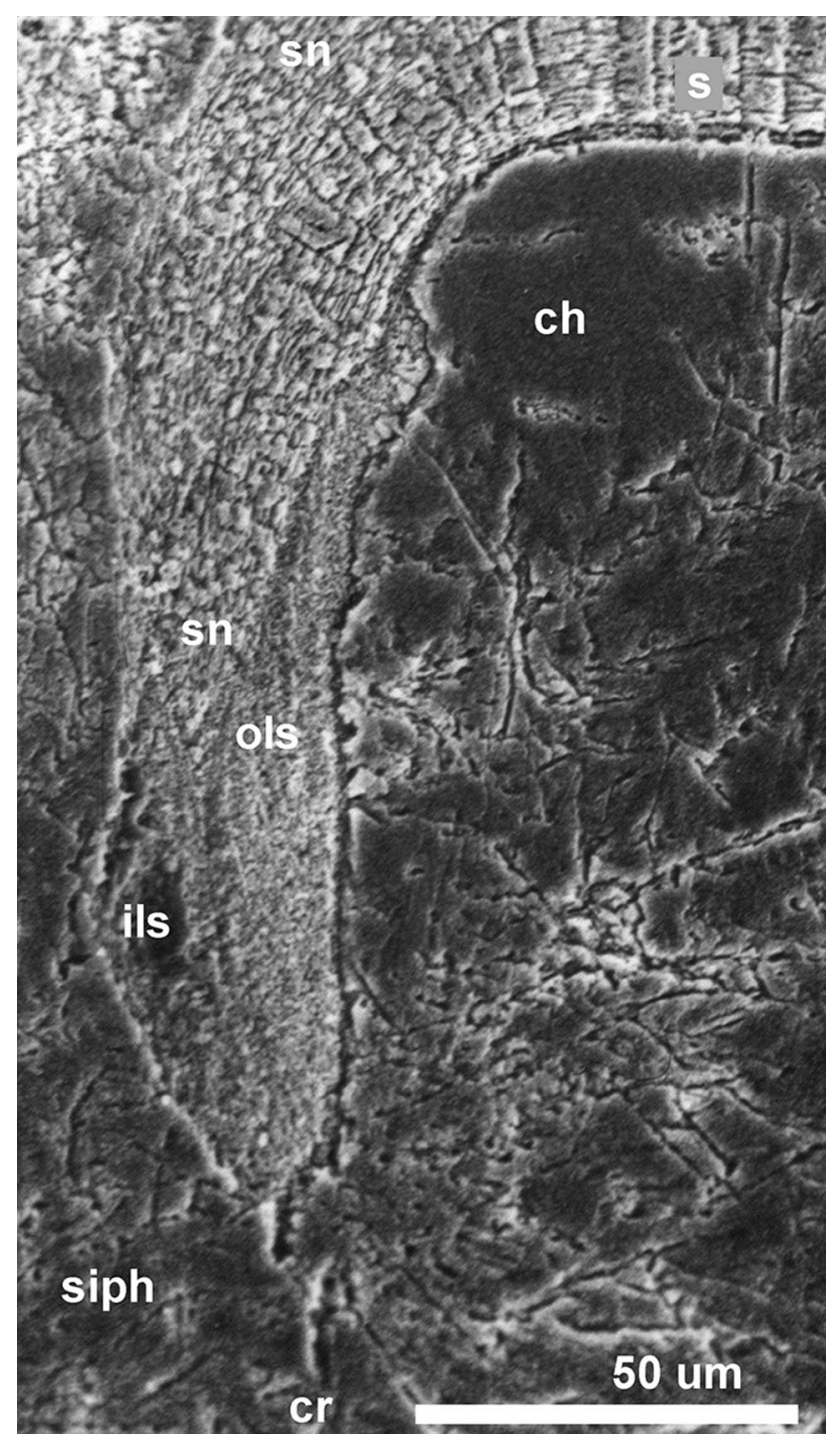

Fig. 8 Dolorthoceras sp. (PIN-1894/100); River Malaya Usa, Polar Urals, NW Russia; Frasnian, Late Devonian. Median conch section. The bipartite lens-shaped structure (sectioned clutch) around the posterior part of the septal neck. Scale bar is $50 \mu \mathrm{m}$. ch chamber, $c r$ connecting ring, ils inner part of lens-shaped structure, $s$ septum, siph siphuncle, $s n$ septal neck, ols outer part of lens shaped structure

development of the fibrous clutches. Therefore, the Late Carboniferous orthoconic cephalopods from the Buckhorn asphalt possibly secreted non-biomineralized rather than originally mineralized connecting rings (see Mutvei 1972, 2016, 2017; Mutvei and Mapes 2018). The opinion that the biomineralized connecting rings are a universal character of the orthocerid cephalopods as well as-based on this idea-the systematic re-assignment of Zhuravlevia from the order Orthocerida Kuhn, 1940 to the order Mixosiphonata Mutvei (2017) likely is misleading.

Cameral deposits Mural and episeptal cameral deposits are present while siphonal deposits are absent. The mural and

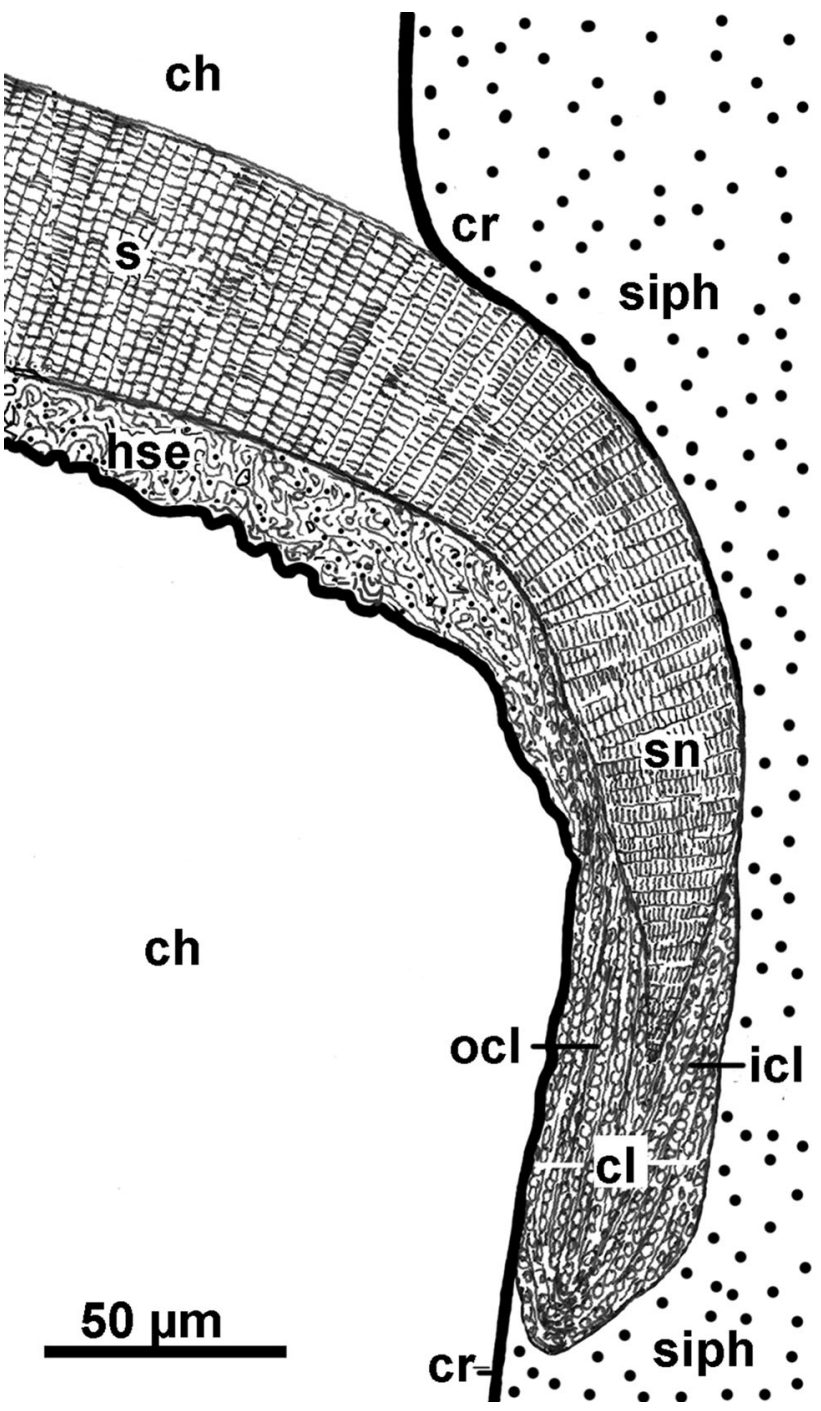

Fig. 9 A schematic drawing of the siphonal tube structure in Dolorthoceras sp. (PIN-1894/100); River Malaya Usa, Polar Urals, NW Russia; Frasnian, Late Devonian. Scale bar is $30 \mu \mathrm{m}$. ch chamber, $\mathrm{cl}$ clutch, $\mathrm{cr}$ connecting ring, hse hyposeptal extension of the clutch along with connecting ring, icl inner part of clutch, $s$ septum, siph siphuncle, ocl outer part of clutch

hyposeptal deposits are thick in the corner areas between the shell wall and adapical septal surfaces (Figs. 1, 3). Of the ten chambers preserved, the six apical ones contain cameral deposits; the four adoral chambers are empty. In the sixth preserved chamber, the cameral deposits are represented only by a single, thin prismatic layer covering the shell wall and a short part of the adapical septal surface (near septal corner); in the fifth chamber, the cameral deposits coat a larger septum and are relatively thick (Fig. 1).

Remarks Like in Dolorthoceras, mural, epi- and hyposeptal septal cameral deposits are present in the early ontogenetic stages in bactritoids and paracoleoids (Doguzhaeva et al. 


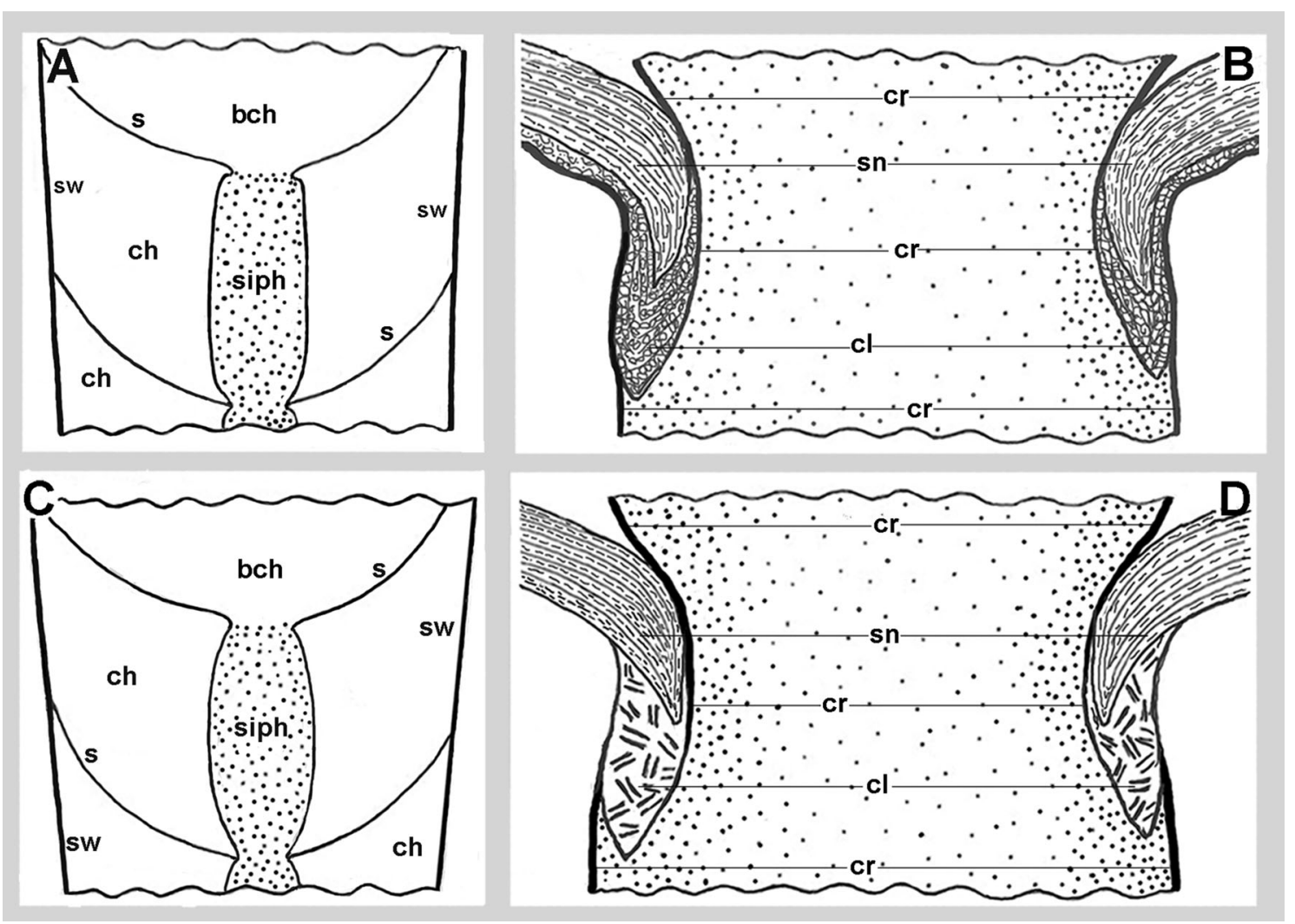

Fig. 10 A schematic drawing of the siphonal tube structures in a, b Dolorthoceras sp. River Malaya Usa, Polar Urals, NW Russia; Frasnian, Late Devonian, and c, d Zuravlevia insperata NW Caucasus, south part of Central Russia; Aptian, Early Cretaceous

2017: figs. 2A, 4A, 5A, 6E; Doguzhaeva 2018a, b: figs. 1B, C; 2B), whilst mural, and hyposeptal cameral deposits are present in the early ontogenetic stages in belemnoids (Doguzhaeva et al. 2014b: fig. 3A, B). The siphonal deposits are also absent in the recorded bactritoids, belemnoids and paracoleoids. In my opinion, the siphonal deposits- that are not present in Dolorthoceras sp.-were erroneously considered as a character of the orthocerids by Mutvei and Mapes (2018).

\section{The Dolorthoceras-type siphonal tube structure and its longevity within the evolution of orthocerids}

The Dolorthoceras-type siphonal tube structure-here established due to exceptionally well-preserved shell material of the Frasnian (Late Devonian) juvenile orthocerid Dolorthoceras sp. from the Polar Urals-is distinguished with the aid of the pronounced intermediate structures between the short septal necks and thin connecting rings (Figs. 9, 10a, b), namely the clutches. These fibrous non-biomineralized clutches around the posterior (after Doguzhaeva 1994; modified). bch, body chamber, ch chamber, $c l$, clutch, $c r$ connecting ring, $s$ septum, siph siphuncle, $s n$ septal neck, $s w$ shell wall

parts of the nacreous septal necks perform the specific conjunctions of the segments of the siphonal tube in the neighbouring chambers of the phragmocone. In each chamber, the anterior end of the connecting ring lies adjacent to the outer surface of the outer part of the clutch and its posterior end lies adjacent to the inner surface of the inner part of the preceding clutch (Fig. 9). The clutches are hence placed within the connecting rings so that the direct contacts between the organic connecting rings and the posterior ends of nacreous septal necks are eliminated due to them (Figs. 2, 4, 6a, b, 8, 9, 10a, b). The conjunction of the siphonal tube segments by means of the clutches results in increasing of the attachment site between the two organic structures: thin permeable connecting rings and fibrous possibly non-permeable clutches. The outer part of the clutch may continue onto the adapical septal surface where it loses the fibrous ultrastructure but retains its nonbiomineralized composition.

The clutches are comparable, to some degree, to the auxiliary (annular, syn.) deposits and cuffs in the siphonal tubes of ammonoids (Druschits and Doguzhaeva 1974, figs. 1, 4; Druschits and Doguzhaeva 1981; Doguzhaeva 1988: text-fig. 3), but have an organic composition and 
thereby differ from these structures, which are calcareous. Westermann $(1971,1982)$ estimated the relative strength of the siphonal tube in ammonoids using the ratio of its diameter and wall thickness and found that the deep-water phylloceratids and lytoceratids have a greater strength than the shallow-water ammonitids. In the former two groups, the auxiliary deposits and cuffs are proportionally longer, whereas in the majority of ammonitids, they are short (Druschits and Doguzhaeva 1974, 1981; Doguzhaeva 1988). These correlations indicate that the siphonal tube structure likely has an influence on the strength of the siphonal tube and, consequently, on the conch strength. Similarly, in Dolorthoceras sp., the clutches apparently strengthened the contacts between the solid nacreous septal necks and possibly chitinous flexible connecting rings and thereby, they enforced the siphonal tube and the conch strength as well. In contrast to biomineralized auxiliary deposits and cuffs of the ammonoids, the organic clutches added less extra-weight to the conch in Dolorthoceras.

The great structural similarity to the Dolorthoceras-type siphonal tube is visible in the Aptian (Early Cretaceous) orthocerid Zhuravlevia in which the "...septum passes into the septal neck proper, which, consequently, is nacreous...The adapical region adjoining the septal neck proper from outside is larger and usually swollen... Unlike the septal neck proper, the swollen part does not pass into the septum... and are subdivided into two portions by a distinct boundary." (Doguzhaeva 1994: text-fig. 4B, p. 895; pl. 2, figs. 2-4). According to terminology employed by Doguzhaeva (1994: text-figs. 4B), the previously used terms 'septal neck proper' and 'swollen additional part of septal neck' correspond, respectively, to 'septal neck' and 'clutch' used in this paper. In Zhuravlevia, the fibrous ultrastructure of the clutches-observed in Dolorthoceras sp.-is apparently not preserved (Fig. 10a-d). Nevertheless, it is much more likely now that, in Zhuravlevia, the conchiolin membranes of the columnar-nacreous septal necks do not continue to the swollen parts of septal necks (= clutches, this paper) and the nacreous lamellae between the conchiolin lamellae of septal necks were not transformed into a mixture of prismatic and organic components as it was mistakenly believed earlier (Mutvei 2017). Because of this, the reassessment of Zhuravlevia and its movement from the order Orthocerida to the order Mixosiphonata (Mutvei 2017) is considered to be misleading as well.

The similarity of the siphonal tube structures between Dolorthoceras and Zhuravlevia-the two orthocerid genera, which were separated by approximately 265 million years of cephalopod evolution-points out the long-term evolutionary persistence of the Dolorthoceras-type siphonal tube structure. Additionally, within the Silurian to Triassic fossil record of orthocerids, the swollen posterior portions of 'septal necks', which are the markers of the clutches in the Devonian Dolorthoceras sp. and the Cretaceous Zhuravlevia, are noticed in the Early Triassic Trematoceras (Zakharov 1996: fig. 1A, B; pl. 1, figs. 1-3; pl. 2, figs. 1-6), Late Carboniferous small-sized orthocones with central or sub-central siphuncles (Erben et al. 1969; Ristedt 1971; Mutvei 1972, 2017; Blind 1988), Hebetorthoceras (Kröger and Mapes 2005: fig. 7.2), Bitaunioceras (Niko et al. 2018: fig. G), Kionoceras (Niko et al. 2007: fig. 2.5), Early Devonian Hemicosmorthoceras, Kopanicoceras, Michelinoceras, Mimogeisonoceras and Sphaerorthoceras (Gnoli 1982: text-figs. 2C1, 6, 7, 8C; pl. 1, figs. 4, 6; pl. 2, figs. 1, 8), as well as Silurian Sphooceras (Turek and Manda 2012: figs. 3A-M, 9A-E, 12A-D, 14A$\mathrm{H})$. It is worth noting that without the knowledge of the fibrous organic clutches associated with the columnarnacreous septal necks and organic connecting rings in the Late Devonian Dolorthoceras one would not expect a primary organic composition of the 'swollen posterior parts additional to septal necks' in Palaeozoic cephalopods.

In summary, the Dolorthoceras-type siphonal tube likely represents a structure of considerable longevity within the evolution of orthocerid cephalopods. Being non-biomineralized, the clutches (which resulted in the 'swollen' form to the septal necks) apparently helped strengthen the septal neck/connecting ring conjunctions and thereby they strengthened the phragmocone against hydrostatic pressure by enhancing the mechanical flexibility of the connections and adding no significant extra-weight to the siphonal tube. However, the prochoanitic septal necks that enabled accelerated growth of the siphonal tube in ammonoids (Doguzhaeva 1988) were not developed in orthocerid cephalopods. Thus, like in ammonoids (Druschits et al. 1976), the development of an advanced specific siphonal tube structure in the orthocerids apparently persisted throughout the approximately 370 million-year-long (Early Ordovician-Early Cretaceous) evolutionary history of the group.

Acknowledgements The author thanks Andy King (Geckoella Ltd, UK) for linguistic correction of the manuscript and Christian Klug (Palaeontological Institute and Museum of the University of Zurich, Switzerland), Harry Mutvei (Swedish Museum of Natural History, Sweden), and Björn Kröger (Finnish Museum of Natural History, Finland) for reviewing and valuable comments.

Open Access This article is distributed under the terms of the Creative Commons Attribution 4.0 International License (http://creative commons.org/licenses/by/4.0/), which permits unrestricted use, distribution, and reproduction in any medium, provided you give appropriate credit to the original author(s) and the source, provide a link to the Creative Commons license, and indicate if changes were made. 


\section{References}

Balashov, Z. G. (1957). The protoconch of an Early Palaeozoic representative of the genus Orthoceras. Doklady Akademy Nauk USSR, 116(5), 855-857. (in Russian).

Balashov, Z. G., \& Zhuravleva, F. A. (1962). Order Orthoceratida. In V. E. Ruzhencev (Ed.), Osnovy paleontologii. MolluscaCephalopoda I (pp. 82-93). Moscow: USSR Academy of Sciences. (in Russian).

Blind, W. (1988). Comparative investigations on the shell morphology and structure in Nautilus pompilius, Orthoceras sp., Pseudorthoceras sp., and Kionoceras sp. In J. Wiedmann \& J. Kullmann (Eds.), Cephalopods present and past O. H. Schindewolf symposium Tübingen 1985 (pp. 273-282). Stuttgart: E. Schweizerbart.

Chernov, G. A. (1961). New data on biostratigraphy of the Upper Devonian of the eastern region of the Bolyshezemel'skaya tyndra. Doklady Akademii Nauk SSSR, 136(1), 183-186. (in Russian).

Chernov, G. A. (1962). Devonian deposits of the eastern region of the Bol'shezemel'skaya tundra. Moscow: Akademiya Nauk SSSR. (in Russian).

Chernov, G. A. (1972). Palaeozoic deposits of the Bol'shezemel'skaya tyndra and the perspectives of its oil-gaz potential. Moscow: Nauka. (in Russian).

De Baets, K., \& Munnecke, A. (2018). Evidence for Palaeozoic orthoconic cephalopods with bimineralic shells. Palaeontology, 61, 173-181.

Doguzhaeva, L. A. (1988). Siphonal tube and septal necks in ammonoids evolution. In J. Wiedmann \& J. Kullmann (Eds.), Cephalopods present and past O. H. Schindewolf symposium Tübingen 1985 (pp. 291-301). Stuttgart: E. Scheizerbart.

Doguzhaeva, L. A. (1994). An early Cretaceous orthocerid cephalopod from north-western Caucasus. Palaeontology, 37, 889-899.

Doguzhaeva, L. A. (1996a). The ultrastructure of the juvenile shells of the Permian Hemibactrites sp. (Cephalopoda: Bactritoidea). Doklady Akademii Nauk, 349(2), 275-279. (in Russian).

Doguzhaeva, L. A. (1996b). Shell ultrastructure of the early Permian bactritella and ammonitella, and its phylogenetic implication. In Jost Wiedemann symposium: Cretaceous stratigraphy, paleobiology and paleobiogeography, abstracts book (pp. 19-25). Tübingen.

Doguzhaeva, L. A. (1996c). Two early Cretaceous spirulid coleoids of the north-western Caucasus: Their shell ultrastructure and evolutionary implications. Palaeontology, 39(3), 681-707.

Doguzhaeva, L. A. (2000). A rare coleoid mollusc from the Upper Jurassic of Central Russia. Acta Palaeontologica Polonica, 45, 389-406.

Doguzhaeva, L. A. (2002a). Adolescent bactritoid, orthoceroid, ammonoid and coleoid shells from the Upper Carboniferous and Lower Permian of the South Urals. Abhandlungen Geologischen Bundesanstalt, 57, 9-55.

Doguzhaeva, L. A. (2002b). Evolutionary trends of Carboniferous coleoids: The ultrastructural view. Berliner Paleobiologische Abhandlungen, 1, 29-33.

Doguzhaeva, L. A. (2018a). Two-fold origin of the Late PaleozoicEarly Cenozoic endocochleate cephalopods: Subclasses Coleoidea Batten, 1888 and Paracoleoidea Doguzhaeva, 2017. In The 10th international symposium cephalopods-present and past. 2018 Mar 25-29 (pp. 26-27). Morocco: Fez University (abstracts volume).

Doguzhaeva, L. A. (2018b). An early Eocene Antarcticeras nordenskjoeldi: The analysis of the "oegopsid coleoid" hypothesis. Historical Biology. https://doi.org/10.1080/08912063.2018. 1491569.
Doguzhaeva, L. A. (2018c). The siphuncle as an indicator of a twofold origin of the internally shelled cephalopods. In The 5th all-Russian symposium contributions to current cephalopod research. Morphology, systematics, evolution, ecology, and biostratygraphy. 2018 October 29-31. (pp. 25-28). Moscow: Paleontological Institute, Russian Academy of Sciences (in Russian).

Doguzhaeva, L. A., Bengtson, S., Reguero, M. A., \& Mörs, Th. (2017). An Eocene orthocone from Antarctica shows convergent evolution of internally shelled cephalopods. PLOS One. https:// doi.org/10.1371/journal.pone.0172169.

Doguzhaeva, L. A., \& Dunca, E. (2015). Siphonal zone structure in the cuttlebone of Sepia officinalis. Swiss Journal of Palaeontology, 134(2), 167-176.

Doguzhaeva, L. A., \& Mapes, R. H. (2017). Beaks from the body chamber of an early Carboniferous shelled longiconic coleoid cephalopod from Arkansas, USA. Lethaia, 54(4), 540-547.

Doguzhaeva, L. A., Mapes, R. H., \& Dunca, E. (2006). A Late Carbonif-erous adolescent cephalopod from Texas (USA), with a short rostrum and a long body chamber. Acta Universitatis Carolinae - Geologica, 49, 59-67.

Doguzhaeva, L. A., Mapes, R. H., \& Mutvei, H. (1999). A Late Carboniferous spirulid coleoid from the southern mid-continent (USA) shell wall ultrastructure and evolutionary implications. In F. Oloriz \& F. J. Rodriguez-Tovar (Eds.), Advancing research on living and fossil Cephalopods (pp. 47-57). New York: Kluwer Academic.

Doguzhaeva, L. A., Mapes, R. H., \& Mutvei, H. (2002a). Early Carboniferous coleoid Hematites Flower and Gordon, 1959 (Hematitida ord. nov.) from Midcontinent (USA). Abhandlungen der Geologischen Bundesanstalt, 57, 299-320.

Doguzhaeva, L. A., Mapes, R. H., \& Mutvei, H. (2003). The shell and ink sac morphology and ultrastructure of the Late Pennsylvanian cephalopod Donovaniconus and its phylogenetic significance. Berliner Paleobiologische Abhandlungen, 3, 61-78.

Doguzhaeva, L. A., \& Mutvei, H. (2003). Gladius composition and ultrastructure in extinct squid-like coleoids: Loligosepia, Trachyteuthis and Teudopsis. Revue de Paléobiologie, 22, 877-894.

Doguzhaeva, L. A., Mutvei, H., \& Donovan, D. T. (2002b). Proostracum, muscular mantle and conotheca in the Middle Jurassic belemnite Megateuthis. Abhandlungen der Geologischen Bundesanstalt, 57, 321-339.

Doguzhaeva, L. A., \& Shkolin, A. A. (1999). Siphuncle of "Loxoceras" (Pseudactinoceratidae) from the Lower Carboniferous of Central Russia: Ultrastructure, phylogenetic implication and functional analysis. In A. J. Rozanov \& A. A. Shevyrev (Eds.), Fossil Cephalopods: Recent advances in their study Paleontological Institute (pp. 271-288). Moscow: Russian Academy of Sciences. (in Russian).

Doguzhaeva, L. A., Weaver, P. G., \& Ciampaglio, C. N. (2014a). A unique late Eocene coleoid cephalopod Mississaepia from Mississippi, USA: New data on cuttlebone structure, and their phylogenetic implications. Acta Palaeontologica Polonica, 59(1), 147-162.

Doguzhaeva, L. A., Weis, R., Delsate, D., \& Mariotti, N. (2014b). Embryonic shell structure of Early-Middle Jurassic belemnites, and its significance for belemnite expansion and diversification in the Jurassic. Lethaia, 47, 49-65.

Doguzhaeva, L. A., Zhuravleva, F. A., Shimansky, V. N., \& Shkolin, A. A. (1996). Shell ultrastructure and systematic position of the early Carboniferous cephalopod Loxoceras. In Special volume dedicated to the 80-anniversary of the Paleontological Society. 42nd session of the all Russian Paleontological Society. Abstracts vol. (pp. 27-28). St. Petersburg (in Russian). 
Druschits, V. V., Bogoslovskaya, M. F., \& Doguzhaeva, L. A. (1976). Evolution of septal necks in ammonoids. Paleontologichesky Zhurnal, 1, 41-56. (in Russian).

Druschits, V. V., \& Doguzhaeva, L. A. (1974). Some morphogenetic characteristics of phylloceratids and lytoceratids (Ammonoidea). Paleontological Journal, 1, 37-48.

Druschits, V. V., \& Doguzhaeva, L. A. (1981). Ammonoids in electron microscope (internal shell structure and systematics of Mesozoic phylloceratids, lytoceratids and six families of the Early Cretaceous ammonitids). Moscow: Moscow State University. (in Russian).

Erben, H. K., Flajs, G., \& Siehl, A. (1969). Die frühontogenetische Entwicklung der Schalenstruktur ectocochleater Cephalopoden. Palaeontographica, Abteilung A, 132, 1-54.

Evans, D. H. (2005). The Lower and Middle Ordovician cephalopod fauna of England and Wales. Monograph of the Palaeontological Society, 623, 1-81.

Fuchs, D., Keupp, H., \& Klug, K. (2018). A critical review of Antarcticeras Doguzhaeva, 2017-teuthid affinities can explain the poorly mineralized phragmocone. Historical Biology. https:// doi.org/10.1080/08912963.2018.1467905.

Gnoli, M. (1982). Lower Devonian orthocone cephalopods from Glesiente and Sulcisi Regions (south-western Sardinia). Bullettino della Società Paleontologica Italiana, 21(1), 73-98.

Hewitt, R. A. (1982). On the connecting rings of Pseudorthoceratacea (Carboniferous Cephalopoda). Journal of Molluscan Studies, 48, 13-17.

Kröger, B. (2008). A new genus of middle Tremadocian orthoceratoids and the Early Ordovician origin of orthoceratoid cephalopods. Acta Palaeontologica Polonica, 53(4), 745-749.

Kröger, B. (2013). The cephalopods of the Boda Limestone, Late Ordovician, of Dalarna, Sweden. European Journal of Taxonomy, O(41), 1-110. https://doi.org/10.5852/ejt.2013.41.

Kröger, B., \& Landing, E. (2008). Onset of the Ordovician cephalopod radiation-evidence from the Rochdale Formation (middle Lower Ordovician, Stairsian) in eastern New York. Geological Magazine. https://doi.org/10.1017/ s0016756808004585.

Kröger, B., \& Mapes, R. H. (2005). Revision of some common Carboniferous genera of North American orthocerid nautiloids. Journal of Paleontology, 79(5), 954-963.

Mutvei, H. (1972). Ultrastructural studies on cephalopod shells. Part 2, Orthoconic Cephalopods from the Pennsylvanian Buckhorn Asphalt. Bulletin of the Geological Institutions of the University of Uppsala, New Series, 3, 263-272.

Mutvei, H. (2015). Characterization of two new superorders Nautilosiphonata and Calciosiphonata and a new order Cyrtocerinida of the subclass Nautiloidea; siphuncular structure in the Ordovician nautiloid Bathmoceras (Cephalopoda). GFF, 137(3), 164-174.

Mutvei, H. (2016). Siphuncular structures in Calciosiphonate nautiloid orders Actinocerida, Orthocerida and Barrandeocerida (Cephalopoda). GFF, 138(2), 295-305.

Mutvei, H. (2017). The new order Mixosiphonata (Cephalopoda: Nautiloidea) and related taxa; estimations of habitat depth based on shell structure. GFF, 139(3), 219-232.

Mutvei, H., \& Dunca, E. (2010). Crystalline structure, orientation and nucleation of the nacreous tablets in the cephalopod Nautilus. Paläontologische Zeitschrift, 84, 457-465.

Mutvei, H., \& Mapes, R. H. (2018). Carboniferous coleoids with mixed coleoid-orthocerid characteristics: A new light on cephalopod evolution. GFF, 140(1), 11-24.
Niko, S., Seuss, B., \& Mapes, R. H. (2018). Desmoinesian (Middle Pennsylvanian) orthocerid cephalopods from the Buckhorn Asphalt Lagerstätte in Oklahoma, Midcontinent, North America. Paleontological Research, 22(1), 20-36.

Niko, S., \& Sone, M. (2015). Gondwanan nautiloid cephalopods from the Ordovician of Myanmar. Paleontological Research, 19(4), 288-293.

Niko, S., Sone, M., \& Leman, M. S. (2007). Two new species of orthocerid cephalopods from the Carboniferous Panching Limestone, West Malaysia. Paleontological Research, 11(4), 331-336.

Ristedt, H. (1971). Zum Bau der orthoceriden Cephalopoden. Palaeontographica, Abteilung A, 137, 155-195.

Seuß, B., Mapes, R. H., Klug, C., \& Nützel, A. (2012a). Exceptional cameral deposits in a sublethally injured Carboniferous orthoconic nautiloid from the Buckhorn Asphalt Lagerstätte in Oklahoma, USA. Acta Palaeontologica Polonica, 57(2), 375-390.

Seuß, B., Titschack, J., Seifert, S., Neubauer, J., \& Nützel, A. (2012b). Oxygen and stable carbon isotopes from a nautiloid from the middle Pennsylvanian (Late Carboniferous) impregnation Lagerstätte "Buckhorn Asphalt Quarry"-primary paleoenvironmental signals versus diagenesis. Palaeogeography, Palaeoclimatology, Palaeoecology, 319(320), 1-15.

Sweet, W. C. (1964). Orthocerida. In R. C. Moore (Ed.), Treatise on Invertebrate Paleontology, Part K, Mollusca 3 (pp. K216K261). Boulder: Geological Society of America and the University of Kansas Press.

Teichert, C. (1988). Main features of cephalopod evolution. In M. R. Clarke \& E. R. Trueman (Eds.), The Mollusca, vol. 12. Paleontology and neontology of cephalopods (pp. 11-79). San Diego: Academic Press.

Teichert, C., \& Glenister, B. F. (1954). Early Ordovician cephalopod fauna from northwestern Australia. Bulletins of American Paleontology, 35, 7-112.

Turek, V., \& Manda, Š. (2012). "An endocochleate experiment" in the Silurian straight-shelled cephalopod Sphooceras. Bulletin of Geosciences, 87(4), 767-813.

Webby, B. D., Paris, F., Droser, M., \& Percival, I. (2004). The great Ordovician biodiversification event. New York: Columbia University Press.

Westermann, G. E. G. (1971). Form, structure and function of shelland siphuncle in coiled Mesozoc ammonoids. Life Science Contributions of the Royal Ontario Museum, 78, 1-39.

Westermann, G. E. G. (1982). The connecting rings of Nautilus and Mesozoc ammonoids: Implications for ammonoid bathymetry. Lethaia, 15, 373-384.

Zakharov, Y. D. (1996). Orthocerid and ammonoids shell structure: Its bearing on cephalopod classification. Bulletin of Natural Science Museum, Tokyo, C, 22(1, 2), 11-35.

Zhuravleva, F. A. (1978). Devonian Orthoceroda. Trudy Paleontologicheskogo Instituta (Vol. 168). Moscow: Nauka. (in Russian).

Zhuravleva, F. A., \& Doguzhaeva, L. A. (1999). Cameral deposits in Pseudorthoceratida and Actinoceratida in scanning electron microscope. In A. J. Rozanov \& A. A. Shevyrev (Eds.), Fossil Cephalopods: Recent advances in their study (pp. 213-269). Moscow: Russian Academy of Sciences, Paleontological Institute. (in Russian).

Zhuravleva, F. A., \& Doguzhaeva, L. A. (2004). Astrovioidea: A new Superorder of Paleozoic cephalopods. Paleontological Journal, 38(Supplementary 1), S1-S73. 